\title{
Time Wasting Activities within the Workplace: Don't Be Apart of Them
}

\author{
Derrick C. Darden \\ Tiffin University, Tiffin, OH, USA \\ Email: derrick.c.darden@gmail.com
}

Received 3 August 2015; accepted 25 August 2015; published 28 August 2015

Copyright (C) 2015 by author and Scientific Research Publishing Inc.

This work is licensed under the Creative Commons Attribution International License (CC BY). http://creativecommons.org/licenses/by/4.0/

(c) (i) Open Access

\begin{abstract}
If you work in an office for a small or large organization, you will notice managers, supervisors, and even your co-workers engaging in time-wasting activities during the day. Typical examples of such activities are talking around the water cooler spreading office gossip or sitting in non-productive meetings. These non-productive, time-wasting activities are common in the workplace. The objective of this article is to help you to identify time-wasting behaviors and what to do about them based on information gathered through observations in the workplace and recent research articles on the topic. In particular, the article identifies three areas of non-productivity such as preoccupation, attending useless meetings, and time-consuming communication unrelated to office business. For both the manager, supervisor and individual worker identification and elimination of the time-wasting activity can foster an organization that promotes efficiency and increases productivity with increase profitability.
\end{abstract}

\section{Keywords}

Non-Productivity, Time Wasting Activities, Boring Meetings, Preoccupation, Productive Worker, Managers

\section{Introduction}

If you work in an office as I do, then you will notice managers, supervisors, and even your co-workers engaging in time-wasting activities during the course of the day. Time-wasting activities can include spreading office gossip, looking at baby or graduation pictures of your co-workers' kids, or sitting in a non-productive meeting. I want to see whether these time wasters exist in my workplace, and they do. During my unofficial eight-hour observational survey in my office, I notice co-workers walking from cubicle to cubicle engaging in frivolous conversation with other co-workers. The topics of discussion range from their favorite sports events (NBA finals) to headline news. I notice that managers and supervisors delay in assigning hot projects promptly because of many 
distractions, from looking at emails to dealing with unexpected walk-ins and incoming phone calls. Another time waster is boring non-productive meetings, which agreements for everyone are a complete waste of time. While conducting the survey, I notice the peak times, and most of these activities occur are in the morning when everybody arrives before lunch, and before everyone leaves to go home at the end of the day. We all are involved, some more than others, in non-productive time-wasting activities. This article will point out those activities that can result in less productivity in organizations and what to do about it.

\section{Three Time Wasting Activities}

The first time-wasting activity that affects productivity is preoccupation with the wrong things instead of the task at hand. Most of us can be preoccupied, wrapped up in our thoughts and feelings and sensations, and not aware or instrumental in the task at hand. When someone is preoccupied, nothing else matters. The good side of preoccupation is the focus that accompanies it, and I'm sure everyone has experienced this phenomenon. For example, when we are in love with someone, nothing else in this world matters at that time. The people around us, even our mother and father, do not matter at the moment. When we are in love, we focus solely on the person we love. We've all had experiences like this; we've all been there. However, when it comes to our workers or our groups, we need to focus our attention on the individual or group when we pass out assignments and talk about the projects at hand. We must not be so preoccupied with emails, talking on the telephone, or entertaining others that we interrupt our meeting with our workers or team. Now, some may argue that they can multitask three or more things at once. Well, the statistics bear witness against that myth [1]. Rosen [1] finds that multitasking's required shifting our attention, especially for the younger generation, can be detrimental to the individual and the culture. As cited by Rosen [1], psychologist William James in 1890, compares the constant shifting of our attention to an immature mind prone to distractions. Many studies point to the cognitive failure of multitasking and compare the mind of a child, which is easily distracted. This is why many states are passing laws that penalize drivers for texting and driving. Focusing on two or more tasks at hand impairs our judgment about what is worthy of our attention [1] [2].

With this in mind, the worker might leave the manager's, or supervisor's office confused about admission or task that has a next-day deadline. This creates uncertainty, anxiety, and an environment that produces low-quality non-productive work [3]. The worker will try to get the full story from other co-workers instead of clarifying with the manager or supervisor. This time waster will come back to cause more problems within the organization and the atmosphere will be intense with confusion. This is why poor communication in the workplace leads to performance problems and time-wasting activities. Preoccupation with the wrong things can lead to low quality and non-productive work.

The second time waster is managers and supervisors holding frivolous meetings that regurgitate information that can be emailed or personally delivered to the affected individuals. Some would say that attending a boring and useless meeting is like going to the doctor for a rectal exam or to the dentist for tooth extraction. I understand that in the federal government meetings are frequent and sometimes non-productive. The old saying in the federal government is that "we have a meeting before the real meeting takes place".

Numerous meetings are unproductive time wasters. As reported in Industry Week [4], out of 613 (men and women) a large majority found that meetings are a big waste of time. As reported in Psychology Today [5], a team of psychologists and neuroscientists has provided the cognitive explanation for why meetings are wasteful. All agree that we have very limited cognitive ability on a daily basis. This is diminished when we don't get enough sleep or take in the right amount of nutrients to help us focus, retain information, and make decisions at these meetings. This is why long meetings, especially discussing projects or contractual agreements, are counterproductive. We make bad decisions or choices in these meetings. On the other hand, if meetings are necessary, we should always have an agenda. If possible, we should provide information a day early so that people can read it prior to the meeting and focus only on the issues at hand; we must leave petty gossip and negative attitudes at the door. Meetings should take no more than one hour, and the less time the better. Finally, we need to create follow-up agenda for the next meeting.

The third time waster is workers engaging in frivolous or time-consuming gossip; even supervisors and managers can be guilty of this. Every organization globally deals with, for example, workers using cell phones/texting more frequently than when regular phones were in use or visiting websites that are not job related, which may cause the worker to shift focus formatively project that needs to become the next day. In paying attention to 
the distracters within the workplace context, the worker is engaging in non-productive time. The individual worker is focusing on a task that is non-productive toward the goal, objective, or mission of the organization. The worker is being sidetracked from the essential task at hand.

As reported by Career Builders, an online survey conducted by Harris poll with 2175 professional participants between February and March 2015 said that the top three time wasters in the workplace are the use of cell phones/texting, with $52 \%$ agreeing that this is a productivity killer, surfing unofficial websites on the job, with $44 \%$ agreeing, and gossiping, with 37\% agreeing [6]. Most organizations have put in place measures to mitigate the time wasters; for example, some companies monitor workers' internet usage via attacking mechanism on servers that pinpoints non-productive work on computers.

To produce efficiency in the workplace and eliminate time wasters, below are three suggestions and tips to implement for an office that is currently non-productive.

\subsection{Suggestion Number One}

Have a plan; the old saying is "if you don't have a plan, then you plan to fail”. This includes managing your time effectively and efficiently; we do this in life with retirement, our jobs, marriage, and even starting a family.

As a supervisor or manager, you are responsible for the forward movement of the organization in accordance with your mission plan, including operations, training of new personnel, and securing equipment and resources. You're the one who knows where the weak links are within the organization. You should develop a plan for the next six months to a year to tackle areas of deficiency within the organization. Don't wait until the busy season to start training folks, getting resources, and securing equipment. Plan ahead to invest in the organization. For example, my office has a timeframe in which we are absolutely busy for two months; no one can go anywhere or take vacation and if people are sick they have to be really sick to stay out of work. Prior to this time, managers and supervisors plan six months out to allow supervisors and team leaders to attend training, and training is conducted with the whole group of specialists. Therefore, in the busy season this year, we experienced increased efficiency and quality and a boost in creativity. This in turn increased job satisfaction and job ownership within the organization. Workers should manage their time by establishing priorities. Schedule large projects up front and avoid distracters such as co-workers piling around your cubicle gossiping; reserve your workspace for productive work only. As a good time manager, schedule frivolous conversation for your breaks or at lunchtime. Remember, the organization hired workers who are reliable, educated, and efficient. High efficiency increases productivity in the workplace, which then increases profitability for both the organization and the individual worker.

\subsection{Suggestion Number Two}

Know yourself and your people. This comes from my old army training; if you take care of your people, they will take care of you. However, you have to know yourself; you have to know your limitations, weaknesses, and strengths. If you don't know yourself and take care of yourself, how can you take care of others? Once you find out who you are and identify those things that hold you back, address those issues. Take care of yourself physically and mentally; don't be the leader who stands in the way of your organization's progress.

If you don't know your people, how can you lead them or plan day-to-day activities and operations with them? You need to get on the floor or in the trenches. Workers are individuals under your control; talk with them, listen to them, and don't be preoccupied with other less important things. Talking with your colleagues, attending to your emails, answering your phone, or addressing a stranger who walks into your office and demands your immediate attention instead of tending to the task at hand sends a signal of disrespect for your workers, both as individuals and as team members.

Managers and supervisors must be aware of the people around them and treat them with respect. When you speak to an individual, get into the position of listening. This may mean that your eyes are glued on this person's eyes and mouth as you listen and repeat back the person's message. Consciously and unconsciously, we all pride ourselves on being effective listeners, but we are frequently preoccupied with other things that take the attention that should all go to the worker.

\subsection{Suggestion Number Three}

Stay focused, stay focused, and stay focused on your workers. You need to talk about hot projects, problems on 
the job, and how to fix those problems. Staying focused means being organized and listening to your team consciously and unconsciously; if you do this, you'll be successful every time. There is no such thing as multitasking; research reveals that a small percentage of the population is true multitaskers. The rest of us are good at stopping one task and focusing on a new task then going back to the first task and picking up where we left off. However, statistics also show that productivity and creativity drop when you do that, so the moral of the story is to focus on one thing at a time. If you do, then you will be successful at many things [3].

\section{Conclusions}

To avoid time wasters and being more productive in the workplace, managers and supervisors need to examine their behaviors that may cause wasted time. Efficiency across the board is the name of the game. The new reality in the workplace is doing more with less. Organizations want workers who are highly efficient in an environment that fosters productivity because increased productivity in the workplace increases profit.

Managers and supervisors need to examine their time-wasting behaviors, such as finding new ways to disseminate information to workers rather than holding frivolous meetings. Workers need to become better time managers and protectors of their workspace so that it doesn't become a hangout spot for co-workers. Additionally, everyone can avoid the big time wasters: use of cell phones, visiting websites that are not job related, and engaging in frivolous conversation. All of these activities can be completed in your off time or on official breaks. Finally, managers, supervisors, and workers should respect each other's time in the workplace. For example, holding workers hostage while the supervisor or manager is preoccupied with distracters such as emails and unscheduled interruptions should be vigorously avoided.

\section{References}

[1] Rosen, C. (2008) The Myth of Multitasking. The New Atlantis, 20, 105-110.

[2] Loukopoulos, D., Dismukes, K. and Barshi, I. (2008) The Multitasking Myth. Ashgate Publishing, Farnham.

[3] Crenshaw, D. (2008) The Myth of Multitasking: How Doing It All Gets Nothing Done. 1st Edition, Jossey-Bass, San Francisco, 144.

[4] Industry Week (2005) Meetings a Waste of Time, Employees Complain. http://www.industryweek.com/archive/meetings-waste-time-employees-complain

[5] Psychology Today (2010) Want to Improve Productivity? Scrap Meetings. https://www.psychologytoday.com/blog/wired-success/201010/want-improve-productivity-scrap-meetings

[6] CareerBuilder (2015) Biggest Time-Wasters at Work? You May Be Surprised. http://www.nbcnews.com/business/careers/biggest-time-wasters-work-you-may-be-surprised-n373671 